\title{
ANALISIS PERBANDINGAN PENGGUNAAN FONDASI SEMI-RAFT PILES DENGAN FONDASI RAFT PILES PADA BANGUNAN APARTEMEN 21 LANTAI
}

\author{
Jossev Chrystalloy ${ }^{1}$ dan Alfred J. Susilo ${ }^{2}$ \\ ${ }^{1}$ Program Studi Sarjana Teknik Sipil, Universitas Tarumanagara, Jl. Letjen S. Parman No.1 Jakarta \\ Email: jossevw@gmail.com \\ ${ }^{2}$ Program Studi Sarjana Teknik Sipil, Universitas Tarumanagara, Jl. Letjen S. Parman No.1 Jakarta \\ Email:alfredsusilo@gmail.com
}

\begin{abstract}
ABSTRAK
Dengan adanya peningkatan estetika konstruksi bangunan dimana perencana struktur sulit menetapkan jarak antar kolom secara teratur sehingga sangat sulit juga untuk membuat pijakan yang terisolasi atau pijakan di setiap konstruksi. Sebagian besar bangunan sipil didukung oleh tanah, sehingga daya dukung dan penurunan tanah menjadi permasalahan. Oleh sebab itu fondasi tikar bertiang atau fondasi rakit bertiang menjadi konstruksi yang populer sehingga dijadikan opsi oleh perencana, karena dapat menangani masalah perbedaan penurunan tersebut serta dapat membantu dalam mengurangi faktor biaya yang akan datang. Kekurangan dari fondasi rakit adalah kurang efektifnya dalam dimensi, volume betonnya dan Inersia yang sama, sehingga awalnya dibutuhkan biaya yang lebih dalam penggunaan volume beton. Perencanaan fondasi semi-rakit bertiang atau fondasi tiang-rakit yang dimodifikasi adalah fondasi yang dirancang sebagai opsi lain untuk menutupi kekurangan dari fondasi rakit bertiang. Fondasi semi-rakit bertiang memiliki kelebihan karena memiliki variasi pada nilai inersianya, dan daya dukungnya serta penurunan yang relatif lebih kecil dibandingkan fondasi rakit bertiang. Dalam studi ini penulis akan membandingkan kekurangan dan kelebihan antara fondasi rakit bertiang dengan fondasi semi-rakit bertiang pada sebuah bangunan apartemen 21 lantai.
\end{abstract}

Kata kunci: tebal raft, fondasi semi-raft piles, penurunan, daya dukung, dan distribusi beban.

\section{PENDAHULUAN}

\section{Latar Belakang}

Sebagian besar bangunan sipil didukung oleh tanah karena bangunan sipil terbagi atas dua bagian yaitu: upper structure dan sub structure yang menghubungkan bangunan atas dan tanah pendukung. Apabila rencana pembangunan berdiri di atas tanah yang bermasalah seperti tanah lunak, maka permasalahan utamanya adalah daya dukung dan penurunan, (Bowles, 1979). Sehingga pemilihan jenis fondasi akan cukup sulit karena faktor kondisi tanah.

Umumnya bangunan bertingkat tinggi didukung oleh fondasi dalam seperti tiang pancang atau tiang bor. Tetapi banyak juga bangunan bertingkat yang saat ini didukung oleh fondasi dangkal seperti fondasi raft atau fondasi rakit. Fondasi ini berupa pelat beton bertulang yang besar. Fungsinya untuk mendistribusikan beban secara merata dari kolom atau dinding ke lapisan tanah di bawahnya.

Seiring perkembangan zaman dengan adanya faktor estetika terhadap konstruksi bangunan yang berpengaruh terhadap perencanaan fondasi, dimana jarak antar kolom yang tidak teratur sehingga sangat sulit untuk membuat pijakan di setiap strukturnya atau isolated pad. Adapun faktor lainnya yang mempengaruhi dalam mendesain fondasi yaitu faktor biaya. Bagaimanapun juga fondasi harus di desain aman terhadap beban statis maupun beban dinamis yang ditimbulkan oleh gempa bumi serta aman terhadap penurunan dan kemungkinan masalah lainnya.

Solusinya dengan menggunakan raft piles foundation pada struktur yang besar atau bertingkat tinggi yang dapat diterapkan pada berbagai jenis dan kondisi tanah. Fondasi raft piles sangat baik dalam hal mengontrol penurunan, kestabilan dan daya dukungnya. Namun dimensinya yang besar, dan seragam membuat raft piles founadtion masih kurang efektif bila dilihat dari tebal pelat fondasi yang dibutuhkan pada setiap kolom atau dinding geser. Sehingga efeknya adalah volume beton, dimana yang sudah kita ketahui bahwa harga ready mix mengalami kenaikkan setiap tahunnya. 
Solusi lainnya adalah dengan membuat fondasi semi-raft piles. Fondasi ini pada dasarnya terdiri dari beberapa fondasi raft piles dimana terdapat pile cap sebagai penghubung antar raft-nya. Fondasi ini memiliki tebal raft yang bervariasi, tergantung pada kebutuhan yang diperlukan berdasarkan beban kolom di atasnya. Tujuan dari desain ini untuk meningkatakan efisiensi terhadap dimensi fondasi yang dibutuhkan, sehingga diharapkan dapat megimbangi antara kebutuhan dan faktor biaya.

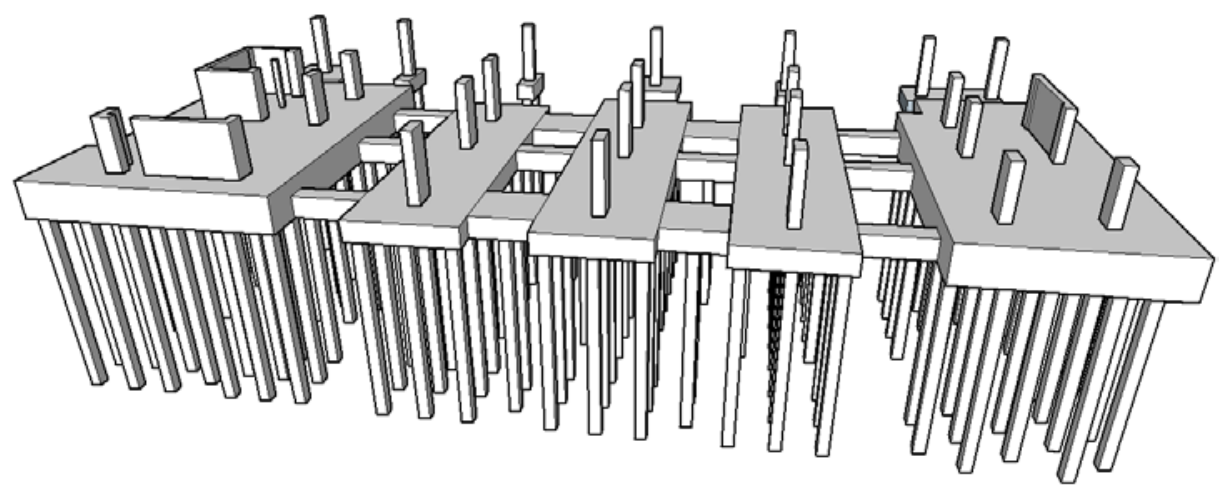

Gambar 1. Model fondasi semi-raft piles

\section{Batasan Masalah}

Batasan-batasan masalah yang diperhatikan dalam penelitian ini terhadap perbandingan desain antara Semi-Raft Piles dan Raft Piles adalah :

- Pembebanan bersifat statis aksial.

- $\quad$ Rencana kedalaman tiang pada fondasi semi-raft piles sama dengan rencana kedalaman tiang fondasi raft piles.

- $\quad$ Perhitungan hanya sampai penurunan, daya dukung, dan tebal minimum fondasi.

\section{Rumusan Masalah}

Adapun rumusan masalah yang dapat kita ambil adalah:

- $\quad$ Besarnya perbedaan nilai daya dukung, dan penurunan antara semi-raft piles dengan raft piles.

- Besarnya load distribution yang dipikul oleh tiang dan raft diantara kedua sistem fondasi tersebut.

- $\quad$ Menghitung tebal efektif fondasi raft.

\section{Tujuan Penelitian}

Berdasarkan rumusan masalah di atas, maka tujuan utama dari penelitian ini adalah sebagai berikut:

- Mengetahui besarnya perbedaan nilai daya dukung, dan penurunan antara semi-raft piles dengan raft piles.

- $\quad$ Mengetahui load distribution yang dipikul oleh tiang dan raft diantara kedua sistem fondasi tersebut.

- Mengetahui tebal efektif fondasi raft yang diperlukan sesuai dengan peraturan yang berlaku.

\section{Manfaat Penelitian}

Dengan adanya penelitian ini dapat diperoleh manfaat antara lain:

- Manfaat teoritis, diharapkan penulis dapat menambah wawasan ilmu pengetahuan dibidang teknik sipil, khususnya dalam bidang fondasi tiang-rakit.

- $\quad$ Manfaat praktis, sebagai informasi tambahan untuk praktisi yang ingin menerapkan fondasi semi-raft piles di lapangan, maupun akademis dalam bidang fondasi tiang-rakit.

\section{LANDASAN TEORI}

\section{Fondasi tiang-rakit atau raft piles}

Fondasi rakit (raft foundation) digunakan untuk menyebarkan beban dari struktur atas ke area yang luas. Fondasi rakit memiliki keunggulan yaitu mengurangi penurunan setempat dimana plat beton akan mengimbangi penurunan diferensial antara posisi beban. Fondasi rakit sering dipergunakan pada tanah lunak atau longgar dengan kapasitas daya dukung yang rendah karena fondasi rakit dapat menyebarkan beban di area yang lebih besar. Sedangkan fondasi tiang kelompok digunakan untuk mengtransfer beban ke lapisan yang lebih dalam sampai didapat jenis tanah yang cukup untuk mendukung beban struktur bangunan. Sehingga jenis tanah yang tidak cocok di dekat permukaan tanah dapat dihindari. Adapun fungsi lain dari tiang kelompok untuk mengurangi penurunan yang terjadi. 
Dalam mengdesain fondasi tiang-rakit, Katzenbach, et.al (1998) mendefinisikan fondasi tiang-rakit sebagai jenis fondasi yang bekerja sebagai struktur komposit dengan memanfaatkan 3 elemen penahan beban, yaitu tiang pancang/bor, fondasi rakit, dan jenis tanah di bawah struktur. Dari 3 elemen tersebut terbentuk empat jenis interaksi antara tiang-tanah, tiang-tiang di sebelahnya, fondasi rakit-tanah, dan fondasi rakit-tiang.

Pada dasarnya, fondasi rakit mendistribusikan beban total dari struktur sebagai tegangan kontak, di samping itu sejumlah tiang juga ikut mendistribusikan beban tersebut melalui daya dukung total tiang.

\section{Daya Dukung Tiang Tunggal}

Dalam menghitung daya dukung tiang tunggal, lebih baik menggunakan metode Meyerhof (1976). Karena metode Meyerhof adalah metode statis empiris, korelasi yang digunakan adalah hasil pembacaan dari penetrasi suatu alat penetrometer yaitu berupa SPT dan CPT.

$$
P_{\text {all }}=\frac{q_{c} A_{p}}{3}+\frac{\sum l_{i} f_{i} \times A_{s t}}{5}
$$

dengan, $\mathrm{P}_{\text {all }}=$ daya dukung izin tekan tiang, $q_{c}=20 \mathrm{~N}$ untuk silt atau clay, $40 \mathrm{~N}$ untuk sand, $\mathrm{A}_{\mathrm{p}}=$ luas penampang tiang, $\mathrm{A}_{\mathrm{st}}=$ keliling penampang tiang, $\mathrm{N}=$ nilai $\mathrm{N}-\mathrm{SPT}, \mathrm{l}_{\mathrm{i}}=$ panjang segmen tiang yang ditinjau, $\mathrm{f}_{\mathrm{i}}=$ gaya geser pada selimut segmen tiang.

\section{Daya dukung fondasi rakit}

Fondasi rakit pada prinsipnya adalah fondasi pelat beton yang lebar. Oleh sebab itu, prinsip perhitungan daya dukungnya sama seperti perhitungan daya dukung fondasi tapak atau pad foundation. Dalam perhitungan digunakan metode Terzaghi (1943), karena Terzaghi yang pertama menyajikan teori yang komprehensif untuk mengevaluasi kapasitas daya dukung fondasi dangkal.

$$
q_{u}=c N_{c}+D_{f} \gamma N_{q}+0.5 \gamma B N_{\gamma}
$$

dengan, $\mathrm{q}_{\mathrm{u}}=$ daya dukung ultimate, $D_{f}=$ kedalaman fondasi, c $=$ kohesi tanah, $\mathrm{B}=$ lebar fondasi, $\mathrm{N}_{\mathrm{c}} ; \mathrm{N}_{\mathrm{q}} ; \mathrm{N}_{\gamma}=$ faktor daya dukung untuk setiap metode.

Tabel 1. Faktor bentuk fondasi terhadap daya dukung

\begin{tabular}{lccc}
\hline \multicolumn{1}{c}{ Bentuk } & $\mathbf{N}_{\mathbf{c}}$ & $\mathbf{N}_{\mathbf{q}}$ & $\mathbf{N}_{\gamma}$ \\
\hline Strip & 1 & 1 & 1 \\
\hline Kotak & 1.3 & 1 & 0.8 \\
\hline Bundar & 1.3 & 1 & 0.6 \\
\hline Persegi panjang & $1+0.3 \frac{B}{L}$ & 1 & $1-0.2 \frac{B}{L}$ \\
\hline
\end{tabular}

\section{Distribusi Beban}

Randolph (1983 \& 1994), untuk mengestimasi perilaku beban dengan penurunan pada fondasi rakit, dapat digunakan metode sederhana yaitu dengan mengestimasi load distribution antara komponen rakit dengan komponen tiang. Distribusi beban tersebut tentu melibatkan kekakuan dari fondasi tiang-rakit, dengan rumusan sebagai berikut:

$$
\beta_{p}=\frac{1}{1+\alpha}
$$

dengan, $\beta_{\mathrm{p}}=$ proporsi beban yang ditahan oleh tiang, $\mathrm{K}_{\mathrm{p}}=$ kekakuan tiang, $\mathrm{K}_{\mathrm{r}}=$ kekakuan fondasi rakit.

Untuk nilai $\alpha$ pada persamaan 3. didapat dari rumusan berikut:

$$
\alpha=\frac{0.2}{1-0.8\left(\frac{K_{r}}{K_{p}}\right)}\left(\frac{K_{p}}{K_{r}}\right)
$$




\section{Penurunan fondasi tiang-rakit}

Poulos dan Davis (1980), mengembangkan sebuah metode mudah dengan membuat estimasi awal mengenai perilaku dari fondasi tiang dan rakit. Metode yang melibatkan dua langkah utama, yaitu estimasi kapasitas beban ultimate dari fondasi dan estimasi perilaku beban terhadap penurunan lewat hubungan sederhana tri-linier.

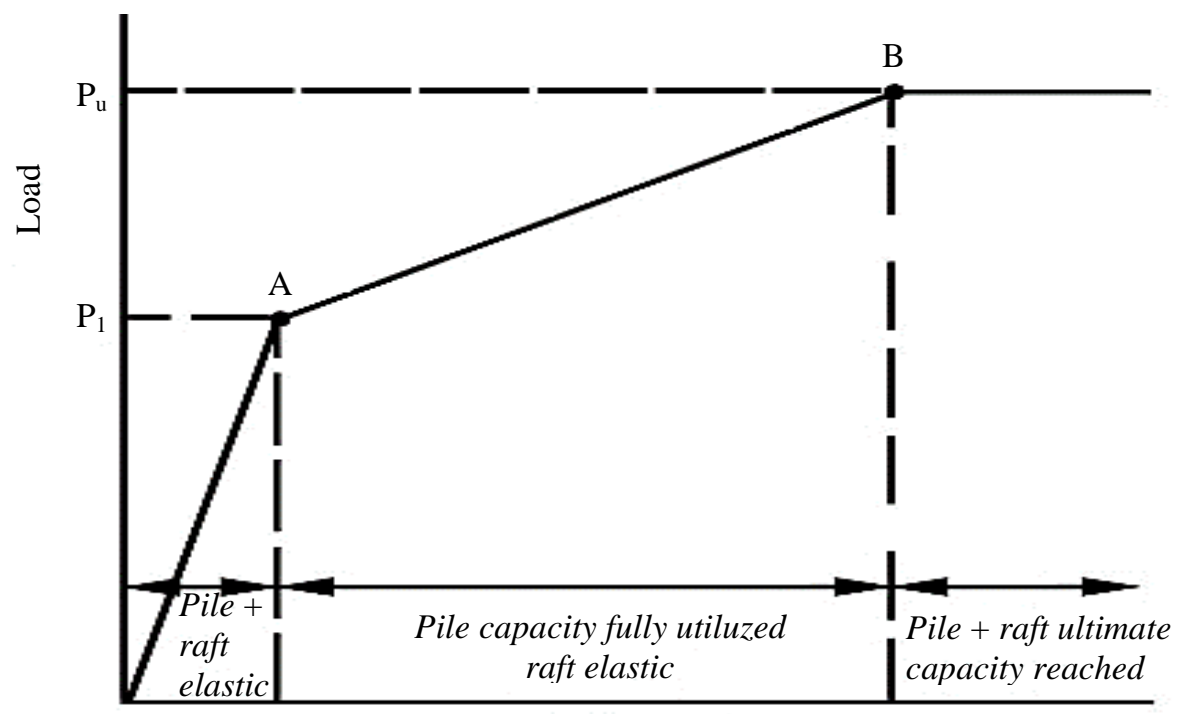

Settlement

Gambar 2. Kurva tri-linier hubungan antara beban dengan penurunan

Besarnya nilai $\mathrm{P}_{1}$ adalah kapasitas beban ultimate kelompok tiang dibagi dengan proporsi beban yang ditahan oleh komponen tiang $\left(\beta_{\mathrm{p}}\right)$ yang didapat dari persamaan 3. Berdasarkan teori dari Poulos dan Davis (1980) jika beban yang bekerja $\left(\mathrm{P}_{\mathrm{W}}\right)$ lebih besar dari daya dukung kelompok tiang $\left(\mathrm{P}_{\mathrm{A}}\right)$, maka untuk menghitung penurunan segera (Immediately Settlement) dengan rumus sebagai berikut:

$$
\rho_{w}=P_{A} R_{G 0.5} \rho_{l i}+\frac{0.947\left(P_{W}-P_{A}\right)\left(1-\mu_{s}^{2}\right)}{B E_{u}}
$$

dengan, $\rho_{w}=$ penurunan segera tiang-rakit, $\rho_{l i}=$ penurunan segera pada tiang tunggal, $\mathrm{P}_{\mathrm{A}}=$ kapasitas daya dukung tiang kelompok, $\mathrm{P}_{\mathrm{W}}=$ beban yang bekerja di atas fondasi tiang-rakit, $\mathrm{R}_{\mathrm{G} 0.5}=$ nilai elastic $\mathrm{R}_{\mathrm{G}}$ tiang-rakit pada kondisi $\mu_{s}=0.5, \mathrm{~B}=$ lebar fondasi rakit, $\mathrm{E}_{\mathrm{u}}=$ modulus deformasi.

Akan tetapi, jika beban yang bekerja $\left(\mathrm{P}_{\mathrm{W}}\right)$ lebih kecil dari daya dukung kelompok tiang $\left(\mathrm{P}_{\mathrm{A}}\right)$, maka untuk menghitung penurunan segera menjadi sebgai berikut:

$$
\rho_{w}=P_{W} R_{G 0.5} \rho_{l i}
$$

Sedangkan untuk menghitung penurunan konsolidasi (Consolidated Settlement) dengan rumus sebagai berikut:

$$
\rho_{C F}=P_{W}\left(R_{G V} \rho_{1 T F}-R_{G 0.5} \rho_{l i}\right)
$$

dengan, $\rho_{C F}=$ penurunan konsolidasi tiang-rakit, $\rho_{l i}=$ penurunan konsolidasi pada tiang tunggal, $\mathrm{R}_{\mathrm{GV}}$, $=$ nilai elastic $\mathrm{R}_{\mathrm{G}}$ dengan $\mu_{s}=\mu_{s}{ }^{\prime}$, Es $=$ modulus elastisitas tanah.

Robert W. Day (2000) menyarankan untuk batas perbedaan penurunan dengan formula sebagai berikut:

$$
\Delta_{\max }=8900\left(\frac{\Delta_{S}}{L}\right)(m m)
$$

dengan, $\Delta_{\max }=$ batas maksimal perbedaan penurunan, $\Delta_{\mathrm{S}}=$ perbedaan penurunan, dan $\mathrm{L}=$ jarak antar kolom.

Poulos (2001) meyarankan batas penurunan berkisar 75 - $135 \mathrm{~mm}$, dan batas distorsi 1/250 - 1/300. Adapun batas penurunan berdasarkan SNI 8460-2017, pasal 9.4.5(e) untuk bangunan tinggi yang menggunakan fondasi tiangrakit, penurunan tidak boleh lebih besar dari $150 \mathrm{~mm}$, dan pada pasal 9.2.4.3 diatur tentang batas distorsi sebesar $1 / 300$. 


\section{Perancangan dengan metode konvensional kaku}

Menurut ACI Committee 336-2002, section 5.3 metode ini digunakan pada kondisi fondasi rakit dianggap sangat kaku, pengaturan jarak antar kolom tidak boleh lebih besar dari 20\%, dan jarak antar kolom dalam dalam baris tidak boleh lebih kecil dari $1.75 / \beta$.

Dari persyaratan yang ada, dapat ditentukan atau direncanakan bahwa fondasi rakit akan di desain sebagai pelat yang sangat kaku atau di desain sebagai elastis.

$$
\beta=\sqrt[4]{\frac{B_{1} K_{s}}{4 E I}}
$$

dengan, $\mathrm{K}_{\mathrm{s}}=$ modulus reaksi tanah (modulus of subgrade reaction), $\mathrm{B}_{1}=$ lebar fondasi rakit, $\mathrm{E}=$ modulus elastisitas dari material, $\mathrm{I}=$ momen inersia dari fondasi rakit.

\section{Punching Shear}

Dalam ACI 318-14 Section 2.5-2.6 atau pada SNI 2847-2013 pada pasal 11.11, mengatur tentang kekuatan geser slab dan fondasi di sekitar kolom, beban terpusat, atau reaksi ditentukan berdasarkan 2 kondisi yaitu geser 1 arah, dan geser 2 arah.

$$
U=\phi \frac{1}{3} \sqrt{f c^{\prime}} b_{o} d
$$

dengan, $\mathrm{U}=$ kuat geser terfaktor, $\mathrm{b}_{\mathrm{o}}=$ lihat gambar 3., $\mathrm{d}$ = tinggi efektif fondasi rakit, fc' = kuat tekan beton (Mpa), $\phi=$ faktor reduksi (0.75).
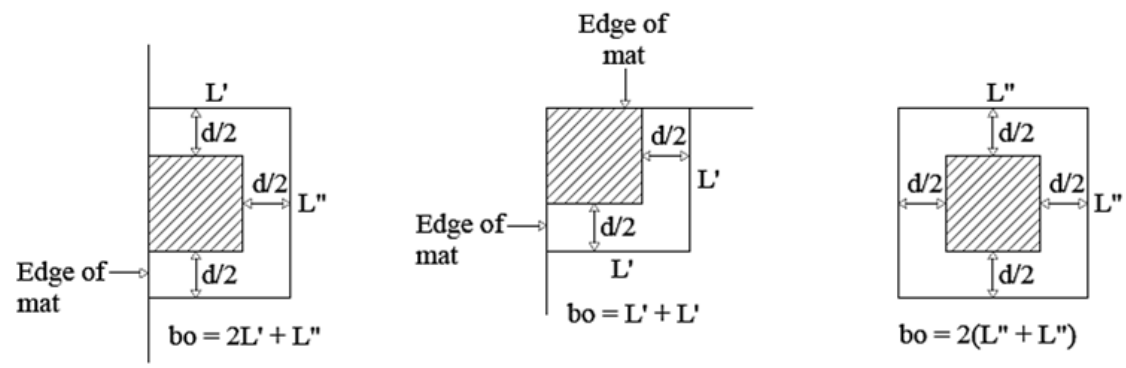

bo $=2\left(L^{\prime \prime}+L^{\prime \prime}\right)$

Gambar 3. Nilai $b_{0}$ berdasarkan posisi kolom

\section{GAMBAR DAN TABEL}

\section{Denah fondasi tiang-rakit}

Denah fondasi semi-raft piles dan letak posisi tiang yang sudah direncanakan pada salah satu proyek apartemen 21 lantai yang berlokasi di Jakarta Barat. Berdasarkan data perencanaan fondasi semi-raft piles ini menggunakan 176 tiang dimana jarak antar tiang $2000 \mathrm{~mm}$.

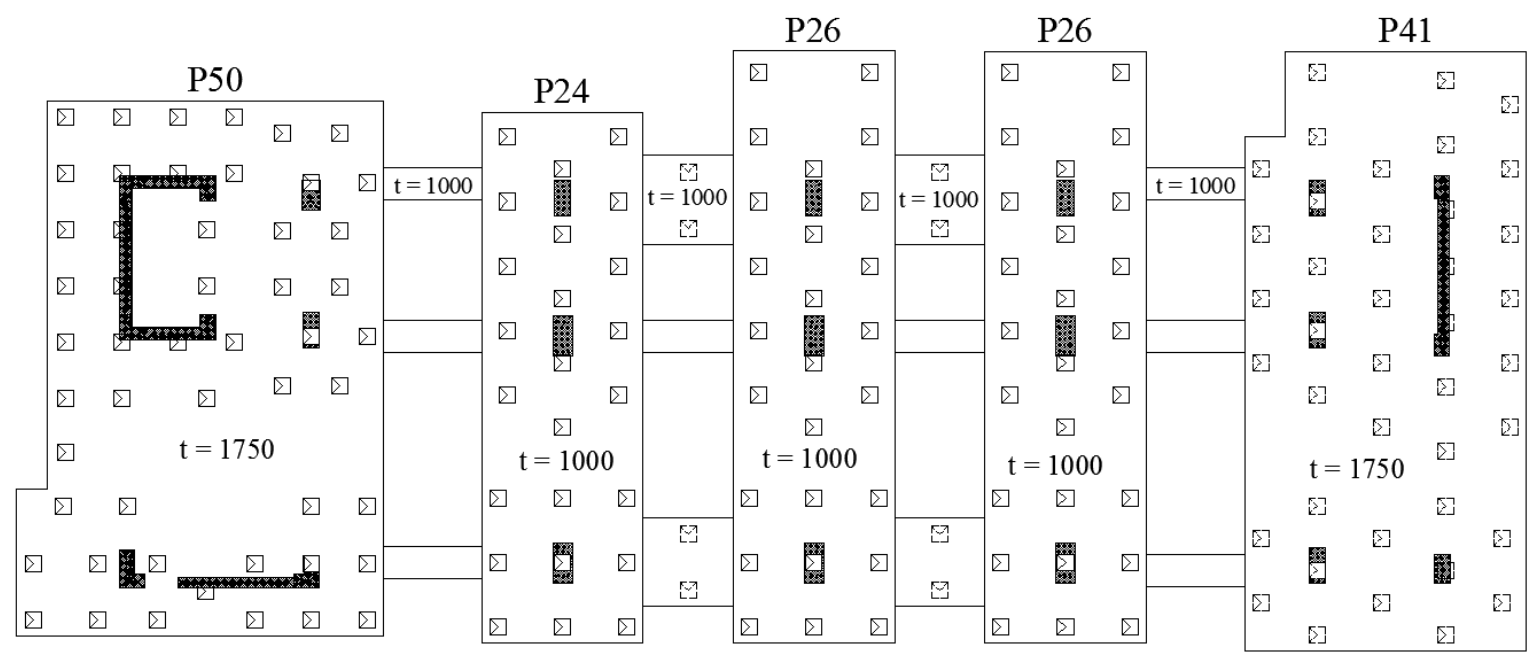

Gambar 4. Denah fondasi semi-raft piles 


\section{Analisis daya dukung tiang-rakit}

Tiang dengan ukuran 500/500 direncanakan terpasang pada kedalaamn -16m, karena berdasarkan hasil penyelidikan tanah diperkiran terdapat lensa yang tebal. Sehingga berdasarkan perhitungan menggunakan metode Meyerhof (1976), rencana nilai daya dukung tekan tiang tunggal yang digunakan sebesar 200.24 ton.

Tabel 2. Daya dukung tekan tiang pada DB1, DB2, dan DB3

\begin{tabular}{|c|c|c|c|c|c|c|}
\hline \multirow[b]{2}{*}{$\begin{array}{c}\text { Depth } \\
\text { (m) }\end{array}$} & \multicolumn{2}{|c|}{ DB-1 } & \multicolumn{2}{|c|}{ DB-2 } & \multicolumn{2}{|c|}{ DB-3 } \\
\hline & N-SPT & $\frac{\mathrm{P}_{\text {all }}}{\text { (ton) }}$ & N-SPT & $\frac{\mathrm{P}_{\text {all }}}{\text { (ton) }}$ & N-SPT & $\frac{\mathrm{P}_{\mathrm{all}}}{\text { (ton) }}$ \\
\hline 2 & 3 & 5.53 & 3 & 5.53 & 5 & 9.21 \\
\hline 4 & 5 & 11.61 & 4 & 9.77 & 7 & 16.89 \\
\hline 6 & 8 & 21.13 & 1 & 8.48 & 4 & 16.97 \\
\hline 8 & 19 & 43.51 & 2 & 10.08 & 4 & 20.17 \\
\hline 10 & 22 & 56.44 & 2 & 11.68 & 7 & 28.89 \\
\hline 12 & 17 & 60.49 & 50 & 184.27 & 25 & 58.98 \\
\hline 14 & 50 & 216.27 & 28 & 53.19 & 35 & 153.47 \\
\hline 16 & 50 & 224.27 & 51 & 200.24 & 50 & 211.47 \\
\hline 18 & 31 & 170.53 & 12 & 52.94 & 33 & 160.08 \\
\hline 20 & 12 & 89.90 & 10 & 58.55 & 10 & 68.79 \\
\hline 22 & 7 & 89.69 & 13 & 71.73 & 12 & 80.78 \\
\hline 24 & 19 & 113.11 & 16 & 84.82 & 24 & 103.95 \\
\hline 26 & 23 & 127.16 & 17 & 95.53 & 22 & 111.32 \\
\hline 28 & 22 & 135.64 & 12 & 99.34 & 25 & 124.26 \\
\hline 30 & 17 & 139.69 & 15 & 112.51 & 20 & 128.30 \\
\hline 32 & 30 & 163.73 & 22 & 129.88 & 25 & 143.46 \\
\hline 34 & 25 & 167.78 & 20 & 137.26 & 28 & 156.39 \\
\hline 36 & 35 & 266.27 & 24 & 151.31 & 23 & 160.44 \\
\hline 38 & 50 & 324.27 & 50 & 299.31 & 27 & 174.48 \\
\hline 40 & 50 & 332.27 & 50 & 307.31 & 30 & 187.41 \\
\hline
\end{tabular}

Dalam menghitung efisiensi tiang kelompok menggunakan metode Feld (1943), dengan melakukan pengurangan 1/16 pada tiang yang berdekatan baik arah sejajar maupun arah diagonal. Dan untuk menghitung daya dukung fondasi rakit menggunakan metode Terzaghi (1943). Perhitungan daya dukung fondasi tiang-rakit dilakukan sebagai berikut:

$q_{\text {all }}=\frac{\left(1+0.3 \frac{8.7}{18.6}\right) 6.8 \cdot 17.5+3.1 \cdot 7.3+\left(1-0.2 \frac{8.7}{18.6}\right) 0.5 \cdot 9.9 \cdot 3.5}{3}=57.68 \mathrm{ton} / \mathrm{m}^{2}$

Daya dukung total $=\left(\mathrm{P}_{\text {all }} \mathrm{x}\right.$ jumlah tiang kelompok $)+\left(\mathrm{q}_{\mathrm{all}} \mathrm{x}\right.$ Luas fondasi rakit $)$

$$
\begin{aligned}
& =(200.24 \times 40)+(57.68 \times 8.732 \times 18.575) \\
& =15203.07 \text { ton }
\end{aligned}
$$

\begin{tabular}{|c|c|c|c|c|c|c|c|c|}
\hline \multirow{2}{*}{\multicolumn{2}{|c|}{ Tipe Raft }} & \multirow{2}{*}{$\begin{array}{c}\text { Jumlah } \\
\text { tiang }\end{array}$} & \multicolumn{2}{|c|}{ Ukuran Fondasi } & \multirow[t]{2}{*}{$\mathrm{E}_{\mathrm{g}}$} & \multirow{2}{*}{$\begin{array}{c}\text { Daya Dukung } \\
\text { Kelompok Tiang } \\
\text { (ton) }\end{array}$} & \multirow{2}{*}{$\begin{array}{c}\text { Daya Dukung } \\
\text { Raft } \\
\left.\text { (ton } / \mathrm{m}^{2}\right)\end{array}$} & \multirow{2}{*}{$\begin{array}{c}\begin{array}{c}\text { Daya Dukung } \\
\text { Total }\end{array} \\
\text { (ton) }\end{array}$} \\
\hline & & & B (m) & $\mathrm{L}(\mathrm{m})$ & & & & \\
\hline \multirow{5}{*}{$\begin{array}{l}\text { Semi- } \\
\text { Raft } \\
\text { Piles }\end{array}$} & P40 & 40 & 8.732 & 18.575 & 0.73 & 5847.01 & 57.68 & 15203.07 \\
\hline & P26 & 26 & 5 & 18.325 & 0.72 & 3748.49 & 53.51 & 8651.41 \\
\hline & P26 & 26 & 5 & 18.325 & 0.72 & 3748.49 & 53.51 & 8651.41 \\
\hline & P24 & 24 & 5 & 16.468 & 0.75 & 3604.32 & 53.85 & 8038.62 \\
\hline & P51 & 51 & 11.4 & 16.6 & 0.68 & 6944.32 & 61.35 & 18553.69 \\
\hline \multicolumn{2}{|c|}{ Raft Piles } & 191 & 18.575 & 46.85 & 0.71 & 27154.55 & 62.19 & 81273.62 \\
\hline
\end{tabular}

Tabel 3. Daya dukung kelompok tiang dan fondasi rakit 
Selanjutnya dibuat grafik perbandingan antara daya dukung total fondasi tiang-rakit $\left(\mathrm{q}_{\mathrm{all}}\right)$ terhadap beban yang bekerja di atas fondasi $\left(\mathrm{P}_{\mathrm{w}}\right)$. Dan `hasilnya dapat dilihat pada Gambar 5.

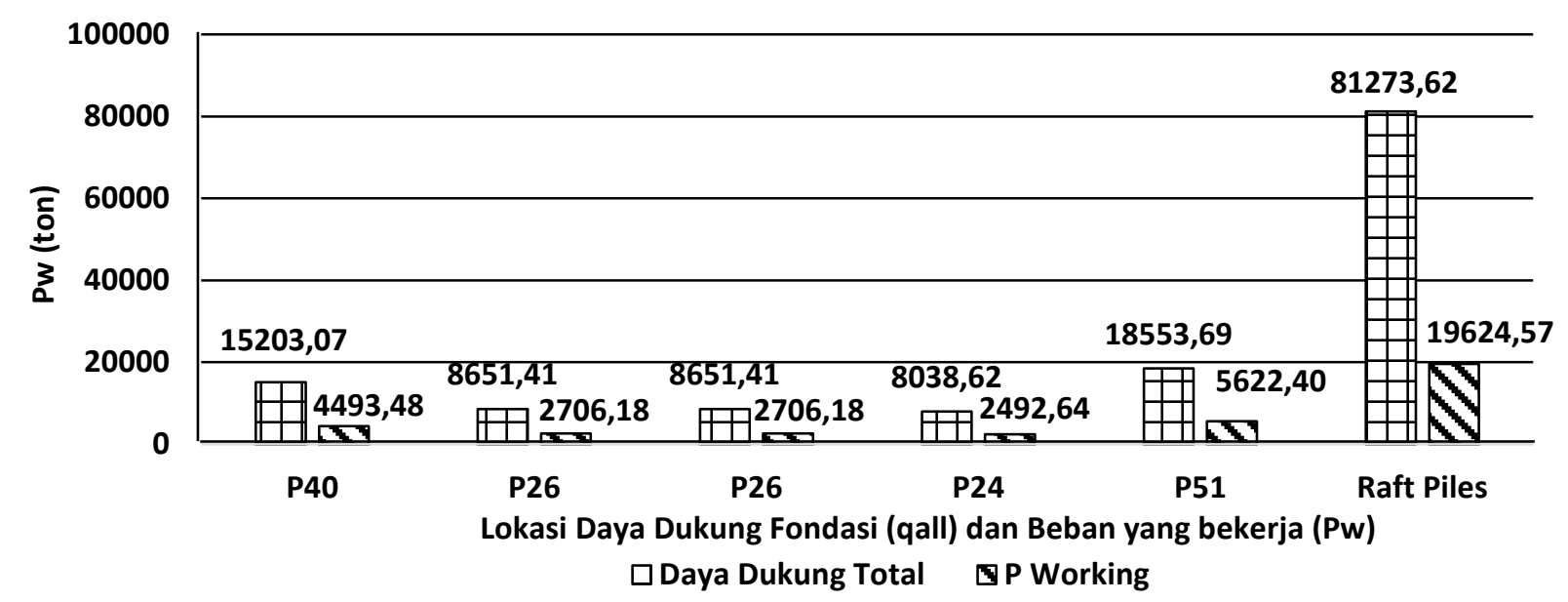

Gambar 5. Grafik perbandingan daya dukung total terhadap beban yang bekerja di atas fondasi tiang-rakit

\section{Distribusi beban}

Dalam SNI 8460-2017 pada pasal 9.7.1 dikatakan bahwa beban yang terdistribusi ke fondasi rakit maksimal 25\% kecuali dapat dibuktikan dengan analisis detail interaksi tanah-tiang-rakit. Sehingga analisis perhitungannya menggunakan metode Randolph (1994).

Tabel 4. Hasil perhitungan load distribution yang diterima oleh tiang $\left(\mathrm{P}_{\mathrm{p}}\right)$ dan fondasi rakit $\left(\mathrm{P}_{\mathrm{r}}\right)$

\begin{tabular}{cccc}
\hline \multicolumn{2}{c}{ Tipe Raft } & $\mathrm{P}_{\mathrm{p}}$ & $\mathrm{P}_{\mathrm{r}}$ \\
\cline { 2 - 4 } & & $(\%)$ & $(\%)$ \\
\hline \multirow{3}{*}{ Semi-Raft } & P40 & 71.74 & 28.26 \\
Piles & P26 & 70.80 & 29.20 \\
& P26 & 70.80 & 29.20 \\
& P24 & 70.88 & 29.12 \\
& P51 & 72.42 & 27.58 \\
\hline \multicolumn{2}{c}{ Raft Piles } & 72.56 & 27.44 \\
\hline
\end{tabular}

\section{Analisis Metode Konvensional Kaku}

Menentukan asumsi yang digunakan untuk menganalisa fondasi rakit dengan mengacu pada tebal fondasi. Dengan mengacu pada ACI Committee 336-2002, suatu fondasi rakit dikatakan kaku jika tebal rencana fondasi lebih besar dari tebal minimum fondasi rakit, dan sebaliknya suatu fondasi rakit dikatakan elastis jika tebal rencana fondasi lebih kecil dari tebal minimum fondasi rakit.

Pada kedua sistem fondasi tiang-rakit di desain dengan mutu beton K-500. Pada fondasi semi-raft piles ketebalan yang digunakan bervariasi dari 1-1.75 m, sedangkan pada fondasi raft piles ketebalan yang digunakan adalah 1.75m. Berdasarkan hasil perhitungan, dapat dilihat pada Tabel 5.

Tabel 5. Kategori desain fondasi rakit

\begin{tabular}{|c|c|c|c|c|c|c|c|c|c|}
\hline \multirow{2}{*}{\multicolumn{2}{|c|}{ Tipe Raft }} & $B_{\text {raft }}$ & $\mathrm{L}_{\text {raft }}$ & $\mathrm{d}_{\mathrm{raft}}$ & $\mathrm{L}_{\text {maks }}$ & \multirow[t]{2}{*}{$\beta$} & $\mathrm{K}_{\mathrm{r}}$ & $\mathrm{h}_{\min }$ & \multirow{2}{*}{$\begin{array}{c}\text { Kategori } \\
\text { Desain }\end{array}$} \\
\hline & & $(\mathrm{m})$ & $(\mathrm{m})$ & $(\mathrm{m})$ & (m) & & $\left(\right.$ ton $\left./ \mathrm{m}^{3}\right)$ & $(\mathrm{m})$ & \\
\hline & P40 & 8.732 & 18.575 & 1.75 & 7.30 & 0.24 & 6921.60 & 1.28 & Rigid \\
\hline Semi- & P26 & 5 & 18.325 & 1 & 7.05 & 0.25 & 6421.20 & 1.19 & Elastis \\
\hline Raft & P26 & 5 & 18.325 & 1 & 7.05 & 0.25 & 6421.20 & 1.19 & Elastis \\
\hline \multirow[t]{2}{*}{ Piles } & P24 & 5 & 16.468 & 1 & 7.05 & 0.25 & 6462.00 & 1.19 & Elastis \\
\hline & P51 & 11.4 & 16.6 & 1.75 & 7.50 & 0.23 & 7362.00 & 1.35 & Rigid \\
\hline \multicolumn{2}{|c|}{ Raft Piles } & 18.575 & 46.85 & 1.75 & 7.80 & 0.22 & 7462.80 & 1.43 & Rigid \\
\hline$* \mathrm{~L}_{\text {maks }}$ & & ntar ko & & & & & & & \\
\hline
\end{tabular}




\section{Analisis penurunan fondasi tiang-rakit}

Pada perhitungan penurunan terdapat dua bagian yaitu penurunan segera dan penurunan konsolidasi. Analisis perhitungan menggunakan metode Poulos dan Davis (1980). Digunakan metode ini karena lebih rasional yaitu dengan menghitung penurunan yang terjadi pada masing-masing elemen (tiang-fondasi rakit-tanah) yang saling berinteraksi.

Berdasarkan hasil perhitungan, maka didapatkan hasil seperti yang ditunjukkan pada Tabel 6.

Tabel 6. Penurunan total fondasi tiang-rakit

\begin{tabular}{|c|c|c|c|c|c|c|c|}
\hline \multicolumn{2}{|c|}{ Tipe $R a f t$} & $\mathrm{~S}_{\mathrm{i}}=\rho_{\mathrm{w}}$ & $S_{C}=\rho_{C F}$ & $\mathrm{~S}_{\mathrm{Tot}}=\rho_{\mathrm{TF}}$ & $\mathrm{S}_{\mathrm{Max}}$ & $\mathrm{S}_{\mathrm{Min}}$ & $\Delta_{\mathrm{S}}$ \\
\hline \multirow{9}{*}{$\begin{array}{l}\text { Semi- } \\
\text { Raft } \\
\text { Piles }\end{array}$} & & & & & \multirow{9}{*}{66.11} & \multirow{9}{*}{33.57} & \multirow{9}{*}{32.54} \\
\hline & $\mathrm{P} 40$ & 37.18 & 19.51 & 56.68 & & & \\
\hline & P26 (ce) & 33.59 & 18.36 & 51.95 & & & \\
\hline & (co) & 23.57 & 12.89 & 36.46 & & & \\
\hline & P26 (ce) & 33.59 & 18.36 & 51.95 & & & \\
\hline & (co) & 23.57 & 12.89 & 36.46 & & & \\
\hline & P24 (ce) & 30.43 & 16.57 & 47.00 & & & \\
\hline & (co) & 21.73 & 11.84 & 33.57 & & & \\
\hline & P51 & 43.83 & 22.28 & 66.11 & & & \\
\hline \multicolumn{2}{|c|}{ Raft Piles } & 65.50 & 32.06 & 97.57 & N/A & N/A & N/A \\
\hline \multicolumn{3}{|c|}{$\begin{array}{l}\text { N/A = Not Available } \\
\text { ce = Settlement at Center } \\
\text { co = Settlement at Corner }\end{array}$} & & & & & \\
\hline
\end{tabular}

Pada fondasi raft piles penurunannya dianggap seragam hampir tidak ada perbedaan penurunan, karena perencanaan awal fondasi raft piles yang di desain dengan ketebalan 1.75 m memiliki kategori desain sangat kaku. Pada fondasi semi-raft piles, perbedaan penurunan yang sebesar $32.54 \mathrm{~mm}$ akan dipikul oleh pile cap penghubung antar fondasi rakitnya.

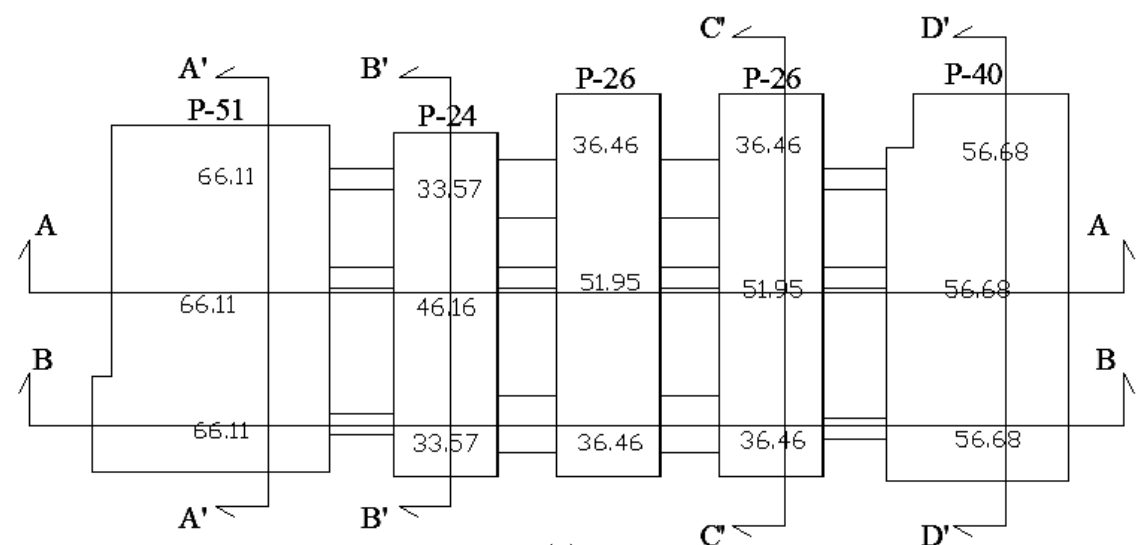

(a)

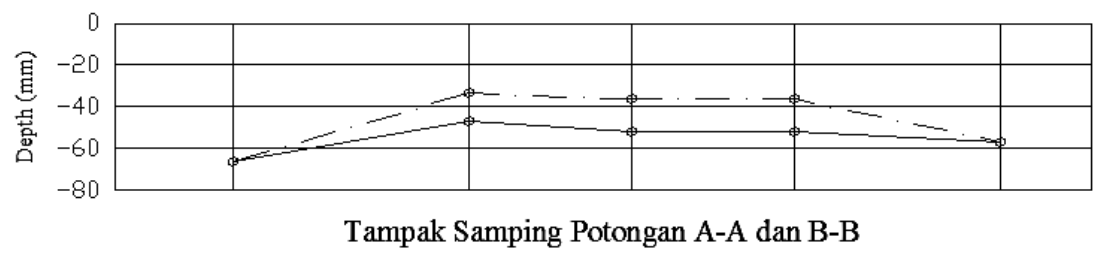

(c)

Gambar 6. Penurunan $S_{\text {tot }}$ pada fondasi semi-raft piles, (a) Besarnya penurunan dilihat dari tampak atas, (b) Grafik penurunan tampak samping pada potongan A'-A'; B'-B'; C'-C' dan D'-D', (c) Grafik penurunan tampak samping pada potongan $A-A$ dan $B-B$ 


\section{Analisis Punching shear}

Dalam menentukan tebal minimum fondasi rakit berdasarkan SNI 2847-2013 dan ACI 318-2014, yaitu dengan memeriksa terhadap dua kondisi terbesar yaitu geser satu arah, dan geser dua arah. Besarnya nilai kuat geser terfaktor $\left(\phi \mathrm{V}_{\mathrm{c}}\right)$ dianggap setara dengan besarnya beban kolom terbesar yang bekerja di atas fondasi rakit, sehingga didapatkan nilai minimum tebal fondasi rakit terhadap kuat geser beton.

Tabel 7. Tebal minimum yang dibutuhkan fondasi rakit

\begin{tabular}{|c|c|c|c|c|c|}
\hline \multirow{2}{*}{\multicolumn{2}{|c|}{ Tipe $R a f t$}} & \multirow{2}{*}{$\begin{array}{c}\mathrm{Q}_{\mathrm{K}} \\
\text { (ton) } \\
\end{array}$} & \multirow{2}{*}{$\begin{array}{c}\mathrm{fc}^{\prime} \\
(\mathrm{MPa}) \\
\end{array}$} & \multicolumn{2}{|c|}{$\mathrm{h}_{\min }$} \\
\hline & & & & $(\mathrm{m})$ & $(\mathrm{mm})$ \\
\hline & $\mathrm{P} 40$ & 786.36 & \multirow{6}{*}{41.50} & 0.75 & 750 \\
\hline Semi- & P26 & 1040.84 & & 0.90 & 900 \\
\hline Raft & P26 & 1040.84 & & 0.90 & 900 \\
\hline \multirow[t]{2}{*}{ Piles } & P24 & 934.74 & & 0.85 & 850 \\
\hline & P51 & 937.07 & & 0.85 & 850 \\
\hline \multicolumn{2}{|c|}{ Raft Piles } & 1040.84 & & 0.85 & 850 \\
\hline
\end{tabular}

\section{KESIMPULAN}

Berdasarkan hasil penelitian dan pembahasan, ada beberapa hal yang disimpulkan berdasarkan tujuan penelitian. Adapun kesimpulan yang diperoleh dapat dijabarkan sebagai berikut:

- $\quad$ Berdasarkan hasil analisis perhitungan, maka didapatkan hasil perbedaan nilai daya dukung dan penurunan pada kedua sistem fondasi sebagai berikut:

Tabel 8. Hasil perbandingan antara fondasi semi-raft piles dengan raft piles

\begin{tabular}{lcc}
\hline & Semi-Raft Piles & Raft Piles \\
\hline Daya dukung total (ton) & 59098.20 & 81273.62 \\
Penurunan total (mm) & 66.11 & 97.57 \\
Perbedaan penurunan (mm) & 32.54 & N/A \\
\hline *N/A = Not Available & & \\
\hline
\end{tabular}

- $\quad$ Distribusi beban yang dipikul oleh tiang kelompok dan fondasi rakit diantara kedua sistem fondasi tersebut tidak jauh berbeda. Untuk beban yang terdistribusi ke tiang kelompok sebesar 71-73\%, sedangkan beban yang akan terdistribusi ke fondasi rakit sebesar 27-29\%. Hal ini terjadi karena dipengaruhi oleh daya dukung fondasi rakit, kekakuan tiang, dan kekakuan fondasi rakit itu sendiri.

- $\quad$ Dari hasil analisis didapatkan tebal minimum beton untuk menahan geser sebesar $900 \mathrm{~mm}$, sedangkan batas minimum kekakuan untuk fondasi semi-raft piles sebesar $1240 \mathrm{~mm}$, dan batas minimum kekakuan untuk fondasi raft piles sebesar $1430 \mathrm{~mm}$.

\section{SARAN}

Berdasarkan hasil penelitian yang dilakukan, maka terdapat beberapa saran yang dapat dilakukan sebagai bentuk pengembangan pengetahuan mengenai fondasi fondasi semi-raft piles selanjutnya.

- $\quad$ Pada fondasi semi-raft piles ini tidak disarankan untuk basement gedung yang lebih dari 1 lantai, karena banyak faktor yang dapat merusak pelat lantai dan dinding basement. Sebagai contoh faktor swelling tanah, tekanan hidrostatik, drainase di bawah fondasi, gaya uplift akibat gempa dan lainnya. Faktor-faktor seperti ini perlu dilakukan pemeriksaan lebih lanjut.

- $\quad$ Pada fondasi semi-raft piles ini perlu dilakukan pemeriksaan terhadap secondary settlement dan kontrol terhadap differential settlement, karena bangunan ini hanya berdiri di atas tanah lensa pada kedalaman $16 \mathrm{~m}$. Hal ini perlu dilakukan untuk mencegah kerusakan-kerusakan pada struktur bangunan, dan kebocoran pada area basement. 


\section{DAFTAR PUSTAKA}

American Concrete Institute. (2002). ACI Committee 336.2R-2002 Suggested Analysis and Design Procedures for Combined Footings and Mats. American Concrete Institute.

American Concrete Institute. (2014). Building Code Requirements for Structural Concrete (ACI 318-14) and Commentary (ACI 318R-14). Michigan: American Concrete Institute.

Badan Standarisasi Nasional. (2013). SNI 2847-2013 Persyaratan Beton Struktural Untuk Bangunan Gedung. Badan Standarisasi Nasional, Jakarta.

Badan Standarisasi Nasional. (2017). SNI 8460-2017 Persyaratan Perancangan Geoteknik. Badan Standarisasi Nasional, Jakarta.

Bowles, J.E. (1979). Physical and Geotechnical Properties of Soils. USA: McGraw-Hill Companies. Inc.

Day, Robert W. (2000). Geotechnical Engineer's Portable Handbook. New York: McGraw-Hill Companies, Inc.

Feld, J. (1943). Discussion on Friction Pile Foundations. ASCE, Vol. 108, P. 149.

Katzenbach, R., U. Arslan, C. Moorman, and O. Reul. (1998). Piles Raft Foundation: Interaction Between Piles and Raft. Darmstadt Geotechnics, Darmstadt University of Technology. Vol. 4, P. 279-296.

Meyerhof, G.G. (1976). Bearing Capacity and Settlement of Pile Foundations. ASCE, JGED, Vol. 102, No. GT3.

Poulos, H.G. (Ed.), and E.H. Davis. (1980). Pile Foundation Analysis And Design. Rainbow-Bridge Book Co., Canada.

Poulos, H.G. (2001). Piled Raft Foundations: Design and Application. Journal Geotechnique, Vol. 51, No. 2, P. 95113.

Randolph, M.F. (1994). Design Methods fo Pile Groups and Piled Raft. XIII ICSMFE, 1994, New Delhi, India.

Terzaghi, Karl. (1943). Theoretical Soil Mechanics. New York: John Wiley, and Sons, Inc. 